\title{
Inulin nanoparticles and silymarin counteract chlorpromazine-induced injury in the liver and kidney of rats
}

\author{
Mosaad A. Abdel-Wahhab ${ }^{1 *}$, Nihad I. Eid ${ }^{2}$, Lamiaa A. Ahmed ${ }^{2}$, Ghada M. Ragab ${ }^{3}$, Aziza A. El-Nekeety ${ }^{1}$, \\ Mohamed M. El-Hakim ${ }^{3}$, Nabila S. Hassan ${ }^{4}$ \\ ${ }^{1}$ Food Toxicology \& Contaminants Dept., National Research Center, Cairo, Egypt. \\ ${ }^{2}$ Pharmacology \& Toxicology Dept., Faculty of Pharmacy, Cairo University, Cairo, Egypt. \\ ${ }^{3}$ Pharmacology \& Toxicology Dept., Faculty of Pharmacy, Misr University for Science and Technology, Cairo, Egypt. \\ ${ }^{5}$ Pathology Dept., National Research Center, Dokki, Cairo, Egypt.
}

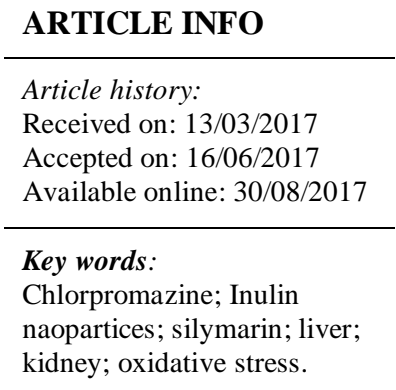

\begin{abstract}
The aim of the current study was to evaluate the protective role of inulin nanoparticles (INPs) prepared by the emulsion method alone or plus silymarin (SIL) against chlorpromazine (CPZ)-induced hepatonephrotoxicity in rats. Eleven groups of female Sprague-Dawley rats were treated orally for 3 weeks as follow: control group, the group treated with CPZ (38.7 mg/kg. b.w in $1 \mathrm{ml}$ saline each $72 \mathrm{~h})$, the groups treated with INPs at low (100 $\mathrm{mg} / \mathrm{kg} \mathrm{b.w})$ or high $(200 \mathrm{mg} / \mathrm{kg} \mathrm{b.w})$ dose, the group treated with SIL $(50 \mathrm{mg} / \mathrm{kg} \mathrm{b.w})$, the groups treated with SIL plus INPs at the two doses and the groups treated with CPZ plus SIL and INPs at the two tested doses. At the end of the treatment period, blood and tissue samples were collected for different biochemical and histological analyses. The results indicated that CPZ induced significant disturbances in liver and kidney function indices, oxidative stress markers, lipid profile, antioxidant enzyme activity and DNA fragmentation as well as the histological changes in the liver and kidney. SIL alone or plus INPs alone at the low or high dose induce insignificant changes in all the tested parameters or pathological changes in the liver and kidney. SIL and INPs at the two doses could induce a pronounced protection in liver and kidney of CPZ-treated animals due to their antioxidant activity and the role of INPs in the enhancement of SIL solubility. It could be concluded that INPs is a promise drug delivery for SIL and could prevent the liver and kidney injury induced by CPZ.
\end{abstract}

\section{INTRODUCTION}

Liver injury induced by drug is the primary reason for the late-stage termination of small-molecule drug discovery research projects. It is also the most attractive for clinical trials of phase III after the exposure of new drug molecules (Vasquez and Peterson, 2017). The main reason for US Food and Drug Administration (FDA) to withdraw a marketable drug after approval is the liver injury induced by the drug (for example, Troglitazone) which accounts more than $50 \%$ of acute cases of liver failure in USA (Bissel et al., 2001). Chlorpromazine (CPZ) is a member of the most important class of the first-generation phenothiazine drug used for the treatment of psychotic disorders

* Corresponding Author

Fax: 202-3337-0931, Tel: 202-2283-1943,

E-mail: mosaad_abdelwahhab @ yahoo.com and is considered as the primary drug used in psychotic disorders treatment (De Haan and Liu, 2009). Unfortunately, the hepatotoxicity of CPZ can't be ignored during the therapeutic use (Derby et al., 1993). The mechanism of hepatotoxicity induced by CPZ is associated with the activation of c-Jun N-terminal kinase (JNK), a member of mitogen-activated protein kinase family (MAPK) which regulate several biological processes involved in the development of inflammation (Gandhi et al., 2010, 2013) and tumorigenesis as well as the neurodegenerative disorders (Davies and Tournier, 2012). Moreover, CPZ inhibits the bile flow in vivo so, it induces cholestasis (Akerboom et al., 1991) and intrahepatic cholestasis in vitro by the alteration of mitochondrial membrane potential and F-actin distribution leading to the alteration of bile acid transport receptors and oxidative stress (Antherieu et al., 2007). Previous reports suggesting that CPZ as neuroleptic 
drug is the extensively studied agent regarding its hepatocanalicular cholestasis (Sulaiman et al., 2006; Uzbekova et al., 2002). However, the assessment and diagnosis of the primary toxicity of CPZ are still limited and do not give accurate prediction of cholestasis (Yang et al., 2015).

Silymarin (SIL) is a complex of flavonoid extracted from Silybum marianum seeds and has a potent hepatoprotective and antioxidant properties. The main isomeric flavonoids of SIL are silydianin, silychristine, silibinin and isosilibinin (Comelli et al., 2007). It is widely used for the treatment of different symptoms including jaundice, hepatitis and cirrhosis. Inulin is one of the fructans group found naturally in plants in the Asteraceae family as a storage carbohydrate (McRorie et al., 2017). It is non digestible, completely soluble and widely found in several plants, fungi and bacteria (Liber and Szajewska, 2013). Chicory is well known to be rich in inulin however, it is found in about 30,000 vegetable products (Wichienchot et al., 2011) including garlic, onions, asparagus and others (van Loo et al., 1995). Inulin showed a verity of pharmacological effects including the decrease of plasma triacylglycerol and hepatic lipogenesis (Letexier et al., 2003), improve the levels of insulin, fasting plasma glucose and hemoglobin and decrease malondialdehyde levels (Pourghassem et al., 2013). Moreover, its anticancer effects (Korbelik and Cooper, 2007) and immunomodulatory properties (Silva et al., 2004) make it widely used in food industry and pharmaceutical applications as stabilizer to slow the release of drug delivery (Barclay et al., 2010).

Recently, an increasing interest has been devoted in the field of drug delivery at nanoscale (Stanwick et al., 2012; Reukov et al., 2011; Ziv-Polat et al., 2012). Nanoparticles (NPs) based drug delivery system could easily penetrate deeply into tissues and fine capillaries because of their sub-cellular and submicron size (Morachis et al., 2012; Ruoslahti, 2012).The development of novel delivery systems for pharmaceutical use and food enrichment is a promising application for nanomaterials (Pang et al., 2017). Therefore, the aim of the current study was to evaluate the protective role of inulin nanoparticles (INPs) and silymarin (SIL) against the hepatonephrotoxicity induced by chlorpromazine (CPZ) in rats.

\section{MATERIALS AND METHODS}

\section{Chemicals and kits}

Chlorpromazine hydrochloride (CPZ), inulin (I) and Silymarin (SIL) were purchased from Sigma Chemical Co. (St. Louis, MO, USA). Kits for Transaminase (ALT, AST) were purchased from Spectrum-diagnostics Co. (Cairo, Egypt), Kits for Adenosine Triphosphate (ATP), Lactate dehydrogenase (LDH), Total bilirubin (TB), alkaline phosphatase (ALP), Superoxide dismutase (SOD), Lipid peroxidation (MDA), Nitric oxide (NO), Glutathione Peroxidase (GPx), Catalase (CAT), cholesterol (Cho), triglycerides (TG), high density liopprotein (HDL), low density lipoprotein (LDL), urea, uric acid and creatinine were purchased from Eagle diagnostics (Dallas, TX, USA). Kits for Uric acid was purchased from FAR Diagnostics Co. (Via Fermi, Italy). ELISA kits for tumor necrosis factor $\alpha(\mathrm{TNF}-\alpha)$ was purchased from RayBiotech, Inc. Co. (Norcross, GA, USA). Tween 80 and blueberry essential oil were purchased from Biodiagnostic Co. (Giza, Egypt). All other chemicals were of the highest purity commercially available.

\section{Preparation and characterization of INPs}

INPs were prepared according to the emulsion method described by Mazloom et al. (2012). In brief, $5 \mathrm{~g}$ of inulin were dissolved in distilled water by magnetic stirring. The solution was kept overnight at ambient temperature in order to warrant a full saturation of wall materials. Blueberry essential oil in the ratio of 1:5 (core: wall) and $1 \%$ of Tween 80 were added to the emulsions. The mixture was stirred by magnetic stirrer for pre-emulsion preparation using an Ultrasonic Liquid Processor (Model S-4000010, USA, operated at $24 \mathrm{KHz}$ for 130s) for the transformation of pre-emulsion to nano emulsion. The emulsion droplets size was determined by Stabilizer (Model PMX200C, Germany). Ultimately, the nano-emulsion was dried by spray drier (Model B191, Buchi, Switzerland) and kept until use.

\section{Experimental animals}

Three-month old female Sprague-Dawley rats (150-200 g each) were obtained from the Animal House, Faculty of Oral and Dental Medicine, Cairo University, Cairo, Egypt. The animals were housed in plastic cages in a room free from any source of chemical contamination, artificially illuminated (12h dark/light cycle) and thermally controlled $\left(25 \pm 1{ }^{\circ} \mathrm{C}\right)$ at the Faculty of Medicine, Cairo University, Cairo, Egypt. The animals were maintained under controlled environmental conditions and fed a standard chow diet and water ad libitum throughout the experimental work. All animals were received humane care in compliance with the guidelines of the Animal Care and Use Committee of the Faculty of Medicine, Cairo University, Cairo, Egypt and the National Institutes of Health (NIH publication 86-23 revised 1985).

\section{Experimental design}

After an acclimatization period of 1 week, the animals were divided into eleven groups (10 rats/ group) and treated orally for 3 weeks as follow: group 1, normal control animals fed on basal diet; group 2, animals treated with CPZ (38.7 mg/kg b.w) in $1 \mathrm{ml}$ of $0.9 \%$ saline solution each $72 \mathrm{~h}$; groups 3 and 4, animals treated daily with low (LD) or high dose (HD) of INPs (100 or 200 $\mathrm{mg} / \mathrm{kg}$ b.w.) respectively; group 5, animals treated daily with SIL (50 mg/kg b.w.); groups 6 and 7, animals treated with SIL plus INPs (LD) or INPs (HD) respectively; groups 8 and 9, animals treated with CPZ plus INPs (LD) or INPs (HD) respectively; group 10 and 11, animals treated with CPZ plus SIL and INPs (LD) or INPs (HD) respectively. Animals within different treatment groups were observed continuously for any signs of toxicity during the 
treatment period. At the termination of the treatment protocol (i.e. day 21), the animals were fasted overnight then the blood samples were collected from the retro-orbital venous plexus under diethyl ether anesthesia. The sera were separated using cooling centrifugation and stored at $-20{ }^{\circ} \mathrm{C}$ until analysis. These sera were used for the biochemical determinations (ALT, AST, ALP, ATP, LDH, TB, Cho, TG, LDL, HDL, urea, uric acid and creatinine) according to the kits instructions using spectrophotometer. The determination of TNF- $\alpha$ was carried out using ELISA kits according to the instructions supplied by the producer.

All animals were sacrificed by cervical dislocation after the collections of blood samples and samples of the liver and kidney of each animal were dissected and weighed then homogenized in phosphate buffer ( $\mathrm{pH} 7.4$ ) to give $20 \% \mathrm{w} / \mathrm{v}$ homogenate as described by Lin et al. (1998). The liver and kidney homogenates were centrifuged at $1700 \mathrm{rpm}$ and $4^{\circ} \mathrm{C}$ for 10 min; the resulted supernatant was stored at $-70{ }^{\circ} \mathrm{C}$ until analysis for the determination of MDA then it was further diluted using phosphate buffer solution to give $2 \%$ and $0.5 \%$ dilutions for the activities of GPX (2\%), CAT and SOD (0.5\%) determination. A second liver and kidney samples from each animal were used for the determination of DNA fragmentation. However, a third liver and kidney samples were fixed in $10 \%$ neutral formalin and paraffin embedded. Sections (5 $\mu \mathrm{m}$ thickness) of each organ for each animal were stained with hematoxylin and eosin (H \& E) and examined using light microscope as described by Drury and Wallington (1980).

\section{Determination of DNA Fragmentation}

The determination of DNA fragmentation was carried out in the liver and kidney according to Perandones et al. (1993). Samples for each animal were dissociated mechanically in the hypotonic lysis buffer ( $1 \mathrm{mM}$ EDTA, $10 \mathrm{mM}$ Tris, $0.2 \%$ Triton X100 and $\mathrm{pH}$ 8.0). The lysate of cell was centrifuged at $11,000 \mathrm{rpm} /$ 15 min using the Heraeus Labofuge 400 R centrifuge (Hanau, Germany). The supernatant contain small DNA fragments was immediately separated and an half of the supernatant was used for gel-electrophoresis. Whereas, the second half and the pellet containing the large pieces of DNA were subjected for the diphenylamine (DPA) determination calorimetrically. The DNA fragmentation percentage was calculated by the formula:
$\%$ DNA fragmentation $=\frac{\text { Supernatant O.D. }}{\text { Supernatant O.D. }+ \text { pellet O.D }} \times 100$

Where: O.D is optical density

\section{Statistical analysis}

All data were subjected to statistical analyses using one was analysis of variance using the procedure of General Linear Models of the Statistical Analysis System (SAS, 1982). The significance of the differences between different groups was determined using Waller-Duncan k-ratio (Waller and Duncan, 1969) and all statements of the significance were based on probability of $\mathrm{P} \leq 0.05$.

\section{RESULTS}

\section{Liver function}

The current results revealed that INPs synthesized by the emulsion method were smooth and free of shrinkage with average particle size of $98.14 \pm 3.6 \mathrm{~nm}$. The in vivo evaluation of CPZ alone or plus INPs at the low or high tested doses singly or plus SIL (Table 1) indicated that CPZ treatment increased significantly the serum ALT, AST, ALP, TB and TNF- $\alpha$ and decreased ATP significantly. Animals received SIL alone were similar to the control regarding all tested parameters, however, those received INPs (LD) alone were similar to the control group except ALP, LDH and TNF- $\alpha$ which were significant decreased and ATP which was significant increased. Treatment with INPs (HD) resulted in a significant increase in ALT, AST and ATP but significantly decreased in TB, however; the other tested parameters were within the normal range of the control group. The animals received INPs (LD) plus SIL were similar to the untreated control group in all the tested parameters except ALT and AST which were significantly higher compared to the control group. However, the group received INPs (HD) plus SIL were similar to the control in all parameters except ATP, was significantly increased than the control group. Treatment with CPZ plus INPs at the two tested doses alone or plus SIL improved all the tested parameters significantly toward the untreated control group. Moreover, INPs (HD) alone or plus SIL could normalize ATP and TB in the groups received CPZ and INPs (LD) plus SIL could normalize TB when co-administrated with CPZ.

Table 1: Effect of INPs and SIL on serum biochemical parameters in rats treated with CPZ.

\begin{tabular}{|c|c|c|c|c|c|c|c|}
\hline Parameter Groups & ALT (U/L) & AST (U/L) & $\mathbf{A L P}(\mathbf{U} / \mathbf{L})$ & TB (U/L) & LDH (U/L) & TNF- $\alpha(\mathrm{pg} / \mathrm{ml})$ & $\operatorname{ATP}(\mathrm{ng} / \mathrm{ml})$ \\
\hline Control & $11.75 \pm 0.81^{\mathrm{a}}$ & $11.75 \pm 0.81^{\mathrm{a}}$ & $124.87 \pm 1.96^{\mathrm{a}}$ & $1.00 \pm 0.06^{\mathrm{a}}$ & $123.12 \pm 4.05^{\mathrm{a}}$ & $33.53 \pm 1.81^{\mathrm{a}}$ & $40.52 \pm 4.13^{a}$ \\
\hline $\mathrm{CPZ}$ & $57.25 \pm 2.63^{\mathrm{b}}$ & $57.25 \pm 2.63^{\mathrm{b}}$ & $508.25 \pm 21.42^{\mathrm{b}}$ & $2.73 \pm 0.34^{\mathrm{b}}$ & $376.62 \pm 18.47^{\mathrm{b}}$ & $146.31 \pm 7.11^{\mathrm{b}}$ & $9.56 \pm 1.22^{\mathrm{b}}$ \\
\hline INPs(LD) & $12.75 \pm 0.77^{\mathrm{a}}$ & $12.75 \pm 0.77^{\mathrm{a}}$ & $118.62 \pm 1.58^{c}$ & $0.93 \pm 0.05^{\mathrm{a}}$ & $112.87 \pm 3.53^{c}$ & $30.52 \pm 1.42^{\mathrm{c}}$ & $48.8 \pm 1.81^{\mathrm{c}}$ \\
\hline INPs(HD) & $13.87 \pm 1.02^{\mathrm{c}}$ & $13.87 \pm 1.02^{\mathrm{c}}$ & $122.75 \pm 3.98^{\mathrm{a}}$ & $0.98 \pm 0.05^{\mathrm{a}}$ & $115.87 \pm 2.36^{\mathrm{c}}$ & $32.45 \pm 1.47^{\mathrm{a}}$ & $49.32 \pm 1.58^{\mathrm{c}}$ \\
\hline SIL & $12.0 \pm 1.05^{\mathrm{a}}$ & $12.0 \pm 1.05^{\mathrm{a}}$ & $123.0 \pm 1.77^{\mathrm{a}}$ & $1.02 \pm 0.06^{\mathrm{a}}$ & $117.13 \pm 2.69^{\mathrm{a}}$ & $31.92 \pm 1.53^{\mathrm{a}}$ & $42.87 \pm 4.11^{\mathrm{a}}$ \\
\hline $\mathrm{INPs}(\mathrm{LD})+\mathrm{SIL}$ & $13.12 \pm 0.97^{\mathrm{c}}$ & $13.12 \pm 0.97^{\mathrm{c}}$ & $124.62 \pm 4.65^{\mathrm{a}}$ & $0.96 \pm 0.08^{\mathrm{a}}$ & $119.0 \pm 3.59^{\mathrm{a}}$ & $34.11 \pm 1.56^{\mathrm{a}}$ & $45.53 \pm 6.43^{\mathrm{a}}$ \\
\hline $\mathrm{INPs}(\mathrm{HD})+\mathrm{SIL}$ & $12.62 \pm 1.10^{\mathrm{a}}$ & $12.62 \pm 1.10^{\mathrm{a}}$ & $124.25 \pm 2.81^{\mathrm{a}}$ & $0.96 \pm 0.03^{\mathrm{a}}$ & $116.12 \pm 3.20^{\mathrm{a}}$ & $34.63 \pm 1.98^{a}$ & $53.82 \pm 6.17^{\mathrm{d}}$ \\
\hline $\mathrm{INPs}_{(\mathrm{LD})}+\mathrm{CPZ}$ & $33.12 \pm 2.91^{\mathrm{d}}$ & $33.12 \pm 2.91^{\mathrm{d}}$ & $322.62 \pm 11.57^{\mathrm{d}}$ & $1.70 \pm 0.13^{\mathrm{c}}$ & $221.37 \pm 12.41^{\mathrm{d}}$ & $84.11 \pm 3.10^{\mathrm{d}}$ & $34.21 \pm 1.56^{\mathrm{e}}$ \\
\hline INPs(HD) + CPZ & $29.75 \pm 1.88^{\mathrm{e}}$ & $29.75 \pm 1.88^{\mathrm{e}}$ & $222.12 \pm 28.49^{\mathrm{e}}$ & $1.47 \pm 0.15^{\mathrm{d}}$ & $216.87 \pm 11.44^{\mathrm{d}}$ & $84.66 \pm 2.55^{\mathrm{d}}$ & $40.65 \pm 3.48^{\mathrm{a}}$ \\
\hline $\mathrm{INPs}_{(\mathrm{LD})}+\mathrm{SIL}+\mathrm{CPZ}$ & $22.12 \pm 1.76^{\mathrm{f}}$ & $22.12 \pm 1.76^{\mathrm{f}}$ & $195.12 \pm 6.01^{\mathrm{f}}$ & $1.13 \pm 0.08^{\mathrm{a}}$ & $183.0 \pm 7.62^{\mathrm{e}}$ & $62.72 \pm 3.95^{\mathrm{e}}$ & $45.18 \pm 5.33^{\mathrm{a}}$ \\
\hline $\mathrm{INPs}(\mathrm{HD})+\mathrm{SIL}+\mathrm{CPZ}$ & $17.87 \pm 2.03^{\mathrm{g}}$ & $17.87 \pm 2.03^{\mathrm{g}}$ & $171.37 \pm 8.52^{\mathrm{g}}$ & $1.06 \pm 0.09^{\mathrm{a}}$ & $178.87 \pm 5.94^{\mathrm{f}}$ & $49.98 \pm 3.11^{\mathrm{f}}$ & $48.37 \pm 5.30^{c}$ \\
\hline
\end{tabular}

Within each column, means with different superscripts are significantly different at $\mathrm{P}<0.05$.

ALT: Alanine aminotransferase; AST: Aspartate aminotransferase; ALP: alkaline phosphatase; TB: Total bilirubin; LDH: Lactate dehydrogenase; TNF- $\alpha$ : Tumor necrosis factor $\alpha$; ATP: Adenosine Triphosphate. 


\section{Kidney function}

The data of kidney function indices (Table 2) indicted that treatment with $\mathrm{CPZ}$ increased significantly the level of creatinine, uric acid and urea. Animals received SIL alone or plus INPs at the low or high dose did not show any significant changes in all kidney function indices except creatinine which was decreased significantly and urea which was increased significantly only in the animals received INPs (HD), SIL and INPs (LD) plus SIL. Animals treated with CPZ plus INPs alone at the two doses or plus SIL showed a significant improvement in all kidney function induces and the low dose of INPs plus SIL could normalize uric acid and urea, however; INPs (HD) plus SIL could normalize uric acid, creatinine and urea when co-administrated with CPZ.

\section{Lipid profile}

The effect of different treatment on lipid profile (Table 3) indicated that CPZ induced a significant increase in the level of cholesterol, triglycerides and LDL and decreased HDL. INPs alone at the two tested doses induced an insignificant reduction in the level of cholesterol, LDL and triglycerides, however; it increased HDL significantly than the control group. Administration of SIL alone did not affect cholesterol, but increased triglycerides and
HDL and decrease LDL significantly. Co- treatment with CPZ plus INPs (LD) or INPs (HD) induced a significant improvement in all lipid profile towards the normal control and interestingly, INPs (HD) plus SIL could normalize HDL in animals treated with CPZ.

\section{Antioxidant enzymes activity}

The results presented in Table (4) revealed that CPZ induced a significant reduction in the activities of GPx, SOD and CAT in the liver and kidney compared to the control. INPs (LD) did not affect these enzymes activity. However, INPs (HD) induced a significant increase in hepatic GPx and CAT in the liver and kidney. SIL increased CAT in both organs but did not induce any significant changes in GPX and SOD. SIL plus INPs (LD) increased CAT in the liver and GPX, SOD and CAT in the kidney, however; SIL plus INPs (HD) increased only hepatic CAT and renal GPx and SOD. The combined treatment with INPs alone at the low or high dose or plus SIL induced a significant improvement in the antioxidant enzymes activity in both liver and kidney of CPZ-treated animals. Interestingly, INPs at either low or high dose could normalize renal SOD and when combined with SIL, it normalized hepatic and renal CAT (Table 4).

Table 2: Effect of INPs and SIL on kidney function indices in rats treated with CPZ.

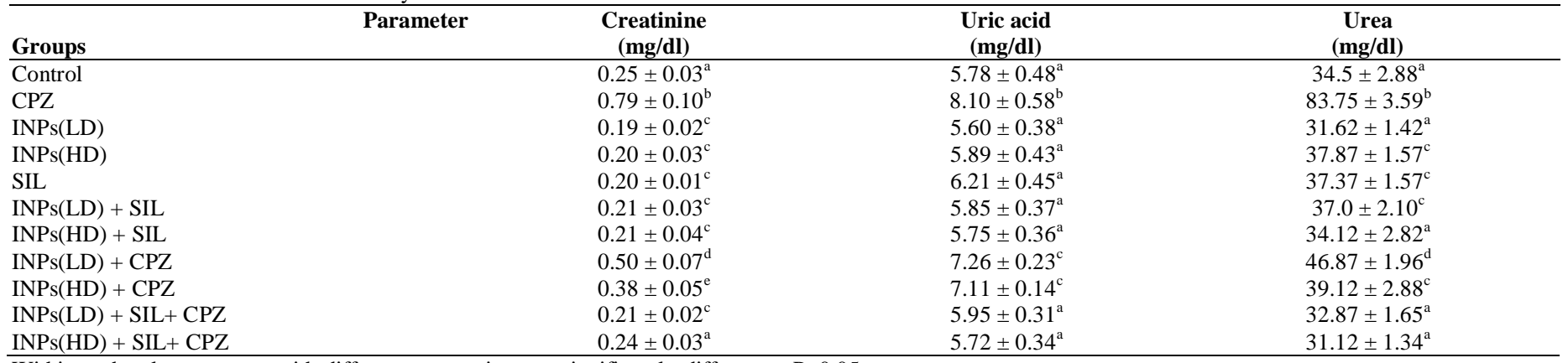

Within each column, means with different superscripts are significantly different at $\mathrm{P}<0.05$.

Table 3: Effect of INPs and SIL on serum lipid profile in rats treated with CPZ.

\begin{tabular}{|c|c|c|c|c|c|}
\hline Groups & Parameter & $\begin{array}{c}\begin{array}{c}\text { Cholesterol } \\
(\mathrm{mg} / \mathrm{dl})\end{array} \\
\end{array}$ & $\begin{array}{c}\text { Triglycerides } \\
\text { (mg/dl) }\end{array}$ & $\begin{array}{c}\text { LDL } \\
(\mathbf{m g} / \mathbf{d l})\end{array}$ & $\begin{array}{c}\text { HDL } \\
(\mathbf{m g} / \mathbf{d l})\end{array}$ \\
\hline Control & & $146.62 \pm 3.10^{\mathrm{a}}$ & $33.68 \pm 3.14^{\mathrm{a}}$ & $74.5 \pm 3.39^{\mathrm{a}}$ & $59.25 \pm 1.41^{\mathrm{a}}$ \\
\hline $\mathrm{CPZ}$ & & $231.25 \pm 7.57^{\mathrm{b}}$ & $107.25 \pm 3.22^{\mathrm{b}}$ & $182.92 \pm 7.09^{\mathrm{b}}$ & $26.88 \pm 1.25^{\mathrm{b}}$ \\
\hline INPs(LD) & & $146.62 \pm 6.72^{\mathrm{a}}$ & $65.75 \pm 3.35^{\mathrm{c}}$ & $71.22 \pm 7.14^{\mathrm{a}}$ & $62.25 \pm 2.08^{\mathrm{a}}$ \\
\hline INPs(HD) & & $147.12 \pm 5.19^{\mathrm{a}}$ & $65.5 \pm 2.79^{c}$ & $72.77 \pm 5.35^{\mathrm{a}}$ & $61.25 \pm 1.41^{\mathrm{a}}$ \\
\hline SIL & & $141.37 \pm 6.56^{\mathrm{a}}$ & $68.63 \pm 2.34^{\mathrm{c}}$ & $61.62 \pm 6.56^{c}$ & $66.0 \pm 1.21^{\mathrm{c}}$ \\
\hline $\operatorname{INPs}(L D)+$ SIL & & $141.37 \pm 4.19^{\mathrm{a}}$ & $31.37 \pm 3.55^{\mathrm{a}}$ & $71.8 \pm 6.54^{\mathrm{a}}$ & $66.13 \pm 1.45^{\mathrm{c}}$ \\
\hline INPs(HD) + SIL & & $142.37 \pm 4.19^{\mathrm{a}}$ & $30.12 \pm 1.38^{\mathrm{a}}$ & $70.5 \pm 4.94^{\mathrm{a}}$ & $63.25 \pm 1.75^{\mathrm{c}}$ \\
\hline $\mathrm{INPs}(\mathrm{LD})+\mathrm{CPZ}$ & & $179.87 \pm 3.86^{\mathrm{c}}$ & $86.25 \pm 3.10^{\mathrm{d}}$ & $126.38 \pm 3.20^{\mathrm{d}}$ & $36.25 \pm 1.99^{\mathrm{d}}$ \\
\hline $\mathrm{INPs}(\mathrm{HD})+\mathrm{CPZ}$ & & $173.75 \pm 6.79^{c}$ & $81.75 \pm 3.97^{\mathrm{d}}$ & $119.27 \pm 6.91^{\mathrm{e}}$ & $38.12 \pm 1.92^{\mathrm{d}}$ \\
\hline $\mathrm{INPs}(\mathrm{LD})+\mathrm{SIL}+\mathrm{CPZ}$ & & $162.87 \pm 3.92^{\mathrm{d}}$ & $71.37 \pm 2.89^{\mathrm{c}}$ & $102.23 \pm 4.90^{\mathrm{f}}$ & $46.37 \pm 1.54^{\mathrm{e}}$ \\
\hline $\mathrm{INPs}(\mathrm{HD})+\mathrm{SIL}+\mathrm{CPZ}$ & & $158.75 \pm 4.52^{\mathrm{e}}$ & $69.5 \pm 4.54^{\mathrm{c}}$ & $91.72 \pm 3.90^{\mathrm{g}}$ & $53.12 \pm 1.75^{\mathrm{a}}$ \\
\hline
\end{tabular}

Within each column, means with different superscripts are significantly different at $\mathrm{P}<0.05$.

LDL: Low density lipoprotein; HDL: High density lipoprotein. 
Table 4: Effect of INPs and SIL on antioxidant enzyme activity in liver and kidney of rats treated with CPZ.

\begin{tabular}{|c|c|c|c|c|c|c|}
\hline \multirow[t]{2}{*}{ Parameter } & \multicolumn{3}{|c|}{ Liver } & \multicolumn{3}{|c|}{ Kidney } \\
\hline & $\begin{array}{c}\text { GPx } \\
\text { (U/mg protein) }\end{array}$ & $\begin{array}{c}\text { SOD } \\
\text { (U/mg protein) }\end{array}$ & $\begin{array}{c}\text { CAT } \\
\text { (U/mg protein) }\end{array}$ & $\begin{array}{c}\text { GPx } \\
\text { (U/mg protein) }\end{array}$ & $\begin{array}{c}\text { SOD } \\
\text { (U/mg protein) }\end{array}$ & $\begin{array}{c}\text { CAT } \\
\text { (U/mg protein) }\end{array}$ \\
\hline Control & $59.27 \pm 1.69^{\mathrm{a}}$ & $3.23 \pm 0.18^{\mathrm{a}}$ & $120.23 \pm 2.32^{\mathrm{a}}$ & $40.63 \pm 2.08^{\mathrm{a}}$ & $5.90 \pm 0.53^{\mathrm{a}}$ & $81.51 \pm 5.10^{\mathrm{a}}$ \\
\hline CPZ & $19.65 \pm 1.53^{\mathrm{b}}$ & $0.44 \pm 0.05^{\mathrm{b}}$ & $56.32 \pm 5.27^{\mathrm{b}}$ & $22.81 \pm 2.55^{\mathrm{b}}$ & $3.10 \pm 0.35^{\mathrm{b}}$ & $44.01 \pm 4.15^{\mathrm{b}}$ \\
\hline INPs(LD) & $58.8 \pm 2.0^{\mathrm{a}}$ & $3.25 \pm 0.13^{\mathrm{a}}$ & $126.12 \pm 3.72^{\mathrm{a}}$ & $44.87 \pm 1.61^{\mathrm{a}}$ & $5.63 \pm 0.48^{\mathrm{a}}$ & $82.7 \pm 4.48^{\mathrm{a}}$ \\
\hline INPs(HD) & $62.21 \pm 4.42^{\mathrm{a}}$ & $3.35 \pm 0.16^{\mathrm{a}}$ & $133.23 \pm 2.38^{\mathrm{c}}$ & $46.52 \pm 3.15^{\mathrm{c}}$ & $5.95 \pm 0.51^{\mathrm{a}}$ & $86.41 \pm 4.59^{\mathrm{c}}$ \\
\hline SIL & $62.75 \pm 3.10^{\mathrm{a}}$ & $3.00 \pm 0.18^{\mathrm{a}}$ & $131.67 \pm 4.13^{\mathrm{c}}$ & $40.46 \pm 1.99^{\mathrm{a}}$ & $5.96 \pm 0.87^{\mathrm{a}}$ & $85.72 \pm 3.08^{c}$ \\
\hline $\mathrm{INP}_{\mathrm{S}}(\mathrm{LD})+\mathrm{SIL}$ & $59.25 \pm 3.23^{\mathrm{a}}$ & $3.15 \pm 0.22^{\mathrm{a}}$ & $136.28 \pm 8.16^{\mathrm{c}}$ & $46.6 \pm 2.57^{\mathrm{c}}$ & $6.40 \pm 0.37^{\mathrm{c}}$ & $87.15 \pm 2.92^{c}$ \\
\hline INPs(HD) + SIL & $58.12 \pm 2.13^{\mathrm{a}}$ & $3.59 \pm 0.19^{\mathrm{a}}$ & $132.78 \pm 4.35^{\mathrm{c}}$ & $47.65 \pm 2.30^{\mathrm{c}}$ & $6.98 \pm 0.32^{\mathrm{d}}$ & $80.81 \pm 4.82^{\mathrm{a}}$ \\
\hline $\mathrm{INPs}(\mathrm{LD})+\mathrm{CPZ}$ & $36.51 \pm 2.67^{\mathrm{c}}$ & $1.43 \pm 0.17^{\mathrm{c}}$ & $83.17 \pm 6.24^{\mathrm{d}}$ & $36.97 \pm 1.61^{\mathrm{d}}$ & $5.21 \pm 0.50^{\mathrm{a}}$ & $63.16 \pm 3.29^{\mathrm{d}}$ \\
\hline $\mathrm{INPs}(\mathrm{HD})+\mathrm{CPZ}$ & $43.07 \pm 1.11^{\mathrm{d}}$ & $2.17 \pm 0.14^{\mathrm{d}}$ & $93.85 \pm 4.59^{\mathrm{e}}$ & $39.8 \pm 3.20^{\mathrm{d}}$ & $5.13 \pm 0.52^{\mathrm{a}}$ & $61.85 \pm 3.52^{\mathrm{d}}$ \\
\hline $\mathrm{INPs}(\mathrm{LD})+\mathrm{SIL}+\mathrm{CPZ}$ & $52.65 \pm 1.80^{\mathrm{e}}$ & $2.61 \pm 0.19^{\mathrm{d}}$ & $118.55 \pm 3.19^{\mathrm{a}}$ & $51.05 \pm 2.11^{\mathrm{e}}$ & $5.36 \pm 0.38^{\mathrm{a}}$ & $78.91 \pm 3.33^{\mathrm{e}}$ \\
\hline $\mathrm{INPs}(\mathrm{HD})+\mathrm{SIL}+\mathrm{CPZ}$ & $55.33 \pm 2.68^{\mathrm{e}}$ & $2.82 \pm 0.18^{\mathrm{d}}$ & $119.56 \pm 6.04^{\mathrm{a}}$ & $48.21 \pm 3.23^{\mathrm{c}}$ & $5.75 \pm 0.51^{\mathrm{a}}$ & $84.27 \pm 5.07^{\mathrm{c}}$ \\
\hline
\end{tabular}

Within each column, means with different superscripts are significantly different at $\mathrm{P}<0.05$.

GPx: Glutathione Peroxidase; SOD: Superoxide dismutase; CAT: Catalase.

Table 5: Effect of INPs and SIL on lipid peroxidation and nitric oxide in liver and kidney of rats treated with CPZ.

\begin{tabular}{|c|c|c|c|c|c|}
\hline \multirow[b]{2}{*}{ Groups } & \multirow[t]{2}{*}{ Parameter } & \multicolumn{2}{|c|}{ Liver } & \multicolumn{2}{|c|}{ Kidney } \\
\hline & & $\begin{array}{c}\text { MDA } \\
\text { (mol/mg protein ) }\end{array}$ & $\begin{array}{c}\text { NO } \\
\text { (U/mg protein) }\end{array}$ & $\begin{array}{c}\text { MDA } \\
\text { (mol/mg protein ) }\end{array}$ & $\begin{array}{c}\text { NO } \\
\text { (U/mg protein) }\end{array}$ \\
\hline Control & & $1.11 \pm 0.059^{\mathrm{a}}$ & $3.34 \pm 0.37^{\mathrm{a}}$ & $1.12 \pm 0.06^{\mathrm{a}}$ & $3.44 \pm 0.29^{\mathrm{a}}$ \\
\hline CPZ & & $18.71 \pm 1.52^{\mathrm{b}}$ & $22.45 \pm 2.33^{\mathrm{b}}$ & $18.71 \pm 1.52^{\mathrm{b}}$ & $15.86 \pm 2.11^{\mathrm{b}}$ \\
\hline $\operatorname{INPs}(\mathrm{LD})$ & & $1.39 \pm 0.14^{\mathrm{a}}$ & $3.69 \pm 0.31^{\mathrm{a}}$ & $1.39 \pm 0.14^{\mathrm{a}}$ & $3.85 \pm 0.44^{\mathrm{a}}$ \\
\hline INPs(HD) & & $1.57 \pm 0.12^{\mathrm{a}}$ & $1.74 \pm 0.14^{\mathrm{c}}$ & $1.57 \pm 0.12^{\mathrm{a}}$ & $3.68 \pm 0.63^{\mathrm{a}}$ \\
\hline SIL & & $1.64 \pm 0.14^{\mathrm{a}}$ & $1.91 \pm 0.19^{\mathrm{c}}$ & $1.64 \pm 0.13^{\mathrm{a}}$ & $3.29 \pm 0.37^{\mathrm{a}}$ \\
\hline $\mathrm{INPs}(\mathrm{LD})+\mathrm{SIL}$ & & $1.43 \pm 0.17^{\mathrm{a}}$ & $1.91 \pm 0.21^{\mathrm{c}}$ & $1.43 \pm 0.16^{\mathrm{a}}$ & $3.51 \pm 0.45^{\mathrm{a}}$ \\
\hline INPs(HD) + SIL & & $1.60 \pm 0.14^{\mathrm{a}}$ & $2.91 \pm 0.65^{\mathrm{a}}$ & $1.60 \pm 0.14^{\mathrm{a}}$ & $3.90 \pm 0.30^{\mathrm{a}}$ \\
\hline $\mathrm{INPs}(\mathrm{LD})+\mathrm{CPZ}$ & & $6.44 \pm 0.83^{\mathrm{c}}$ & $7.96 \pm 0.58^{\mathrm{d}}$ & $6.44 \pm 0.83^{\mathrm{c}}$ & $7.84 \pm 0.66^{\mathrm{c}}$ \\
\hline INPs(HD) + CPZ & & $5.44 \pm 0.63^{\mathrm{c}}$ & $6.13 \pm 0.37^{\mathrm{e}}$ & $5.43 \pm 0.63^{\mathrm{c}}$ & $8.21 \pm 0.93^{\mathrm{d}}$ \\
\hline INPs(LD) + SIL+CPZ & & $4.175 \pm 0.51^{\mathrm{d}}$ & $4.52 \pm 0.55^{\mathrm{e}}$ & $4.17 \pm 0.51^{\mathrm{d}}$ & $4.54 \pm 0.51^{\mathrm{e}}$ \\
\hline INPs(HD) + SIL+CPZ & & $2.655 \pm 0.35^{\mathrm{e}}$ & $3.42 \pm 0.51^{\mathrm{a}}$ & $2.65 \pm 0.35^{\mathrm{e}}$ & $4.74 \pm 0.87^{\mathrm{e}}$ \\
\hline
\end{tabular}

Within each column, means with different superscripts are significantly different at $\mathrm{P}<0.05$.

MDA: Malondialdehyde; NO: Nitric oxide.

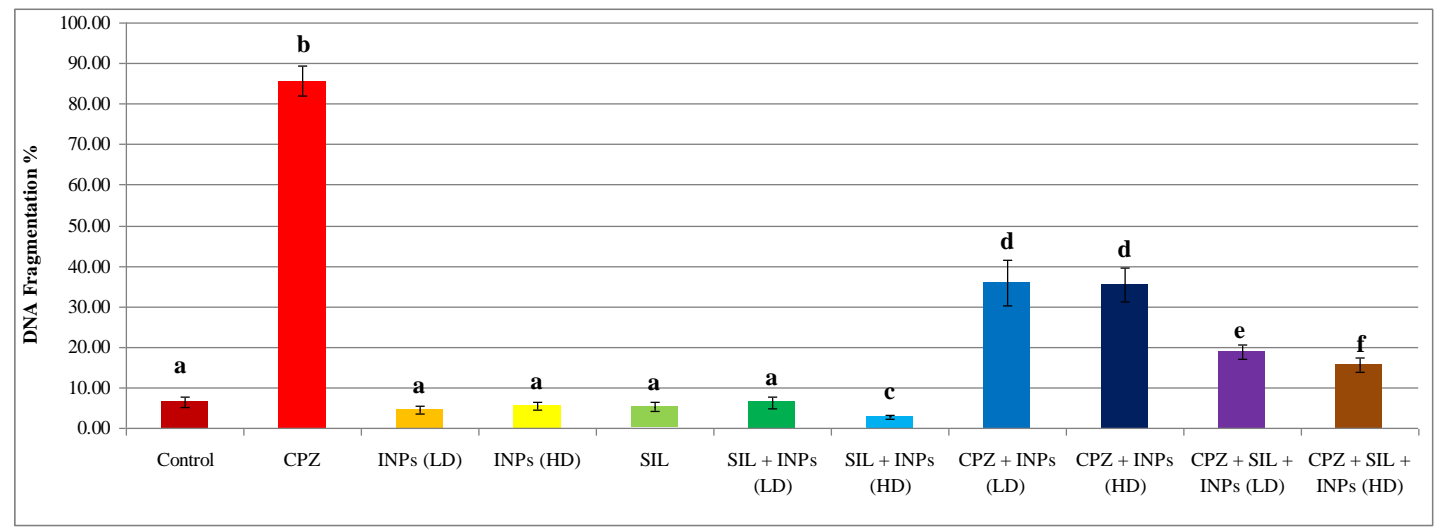

Fig. 1: Effect of INPs and SIL on DNA fragmentation in liver tissues of rats treated with chlorpromazine.

\section{Oxidative stress markers}

The results of NO and lipid peroxidation expressed as MDA in the liver and kidney (Table 5) revealed that CPZ treatment increased hepatic and renal MDA and NO significantly. The administration of CPZ and INPs at the two tested doses plus SIL resulted in a significant improvement in NO and MDA towards the control level. Moreover, hepatic NO was only normalized in rats treated with CPZ and INPs (HD) plus SIL.

\section{DNA fragmentation}

The percentage of DNA fragmentation in hepatic (Fig. 1) and renal (Fig. 2) tissue and the gel electrophoresis expressed as a
DNA ladder showed a series of fragments which multiples of 180200 bp in liver (Fig. 3) and kidney (Fig. 4) and indicated that CPZ caused pronounced DNA fragmentation in both organs compared to the control rats.

Treatment with INPs at the two tested doses, SIL or SIL plus INPs (LD) did not significantly affect hepatic or renal DNA fragmentation except the group received INPs (HD) plus SIL which DNA fragmentation showed a significant decrease. Cotreatment with CPZ plus INPs (LD) or INPs (HD) and SIL improved significantly DNA fragmentation in hepatic and renal tissue, although these percentages of DNA fragmentation were still higher than the control group. 


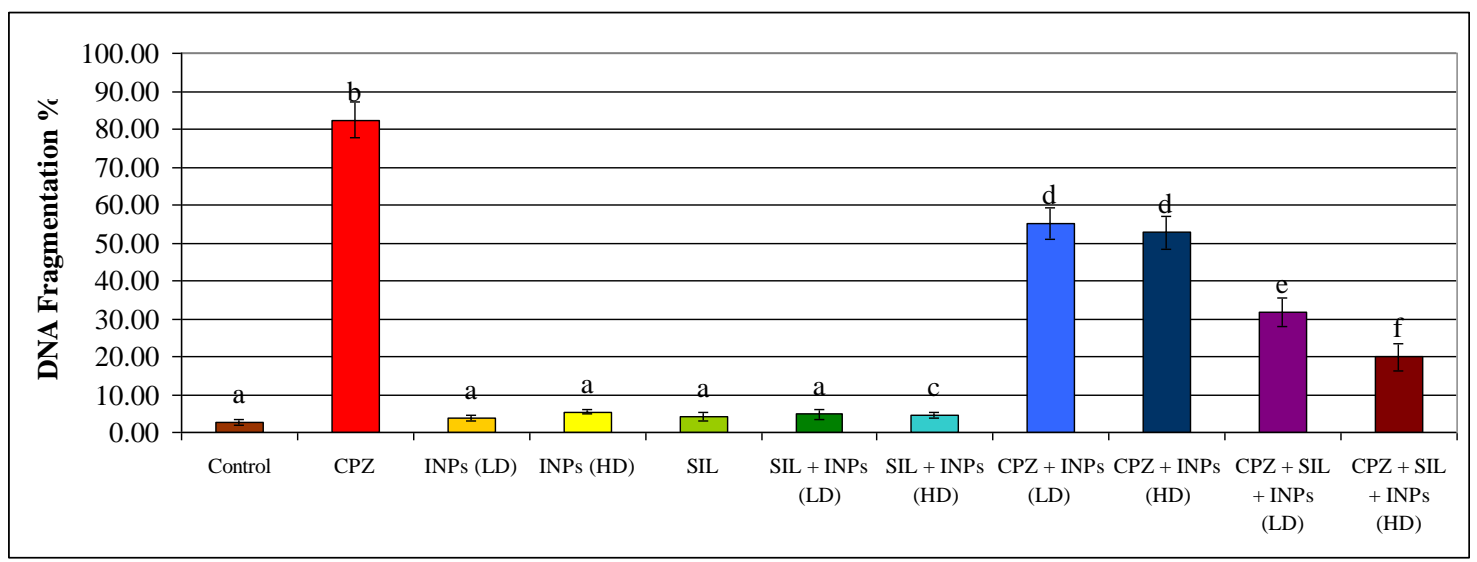

Fig. 2: Effect of INPs and SIL on DNA fragmentation in kidney tissues of rats treated with chlorpromazine.

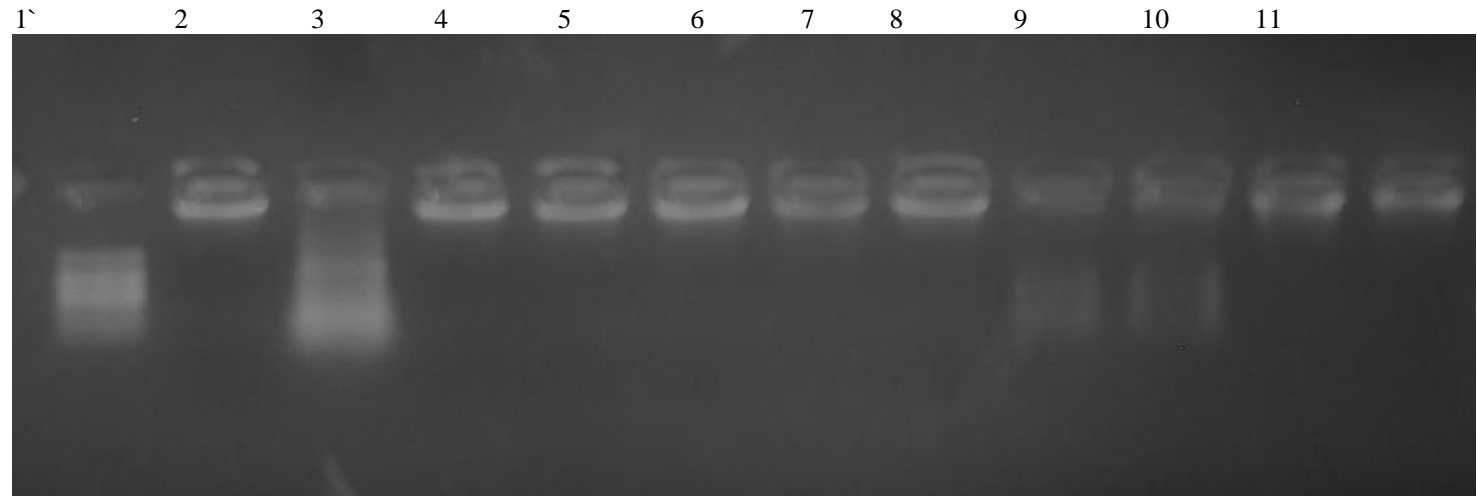

Fig. 3: Effects of inulin nanoparticles and SIL on DNA fragmentation of hepatic tissue in CPZ-treated rats. Agarose gel electrophoretic pattern of DNA isolated from liver tissue of different groups. Lane M: phi x marker, Lane 1: Control, Lane 2: low dose of INPs, Lane 3: high dose of INPs, Lane 4: CPZ, Lane 5: SIL, Lane 6: INPs (LD)+ SIL , Lane 7 : SIL + INPs(HD), Lane 8: CPZ+ INPs(LD), Lane 9: CPZ + INPs (HD), Lane 10: CPZ+ SIL+ INPs(LD) and Lane 11: CPZ+ $\mathrm{SIL}+\mathrm{INPs}(\mathrm{HD})$.

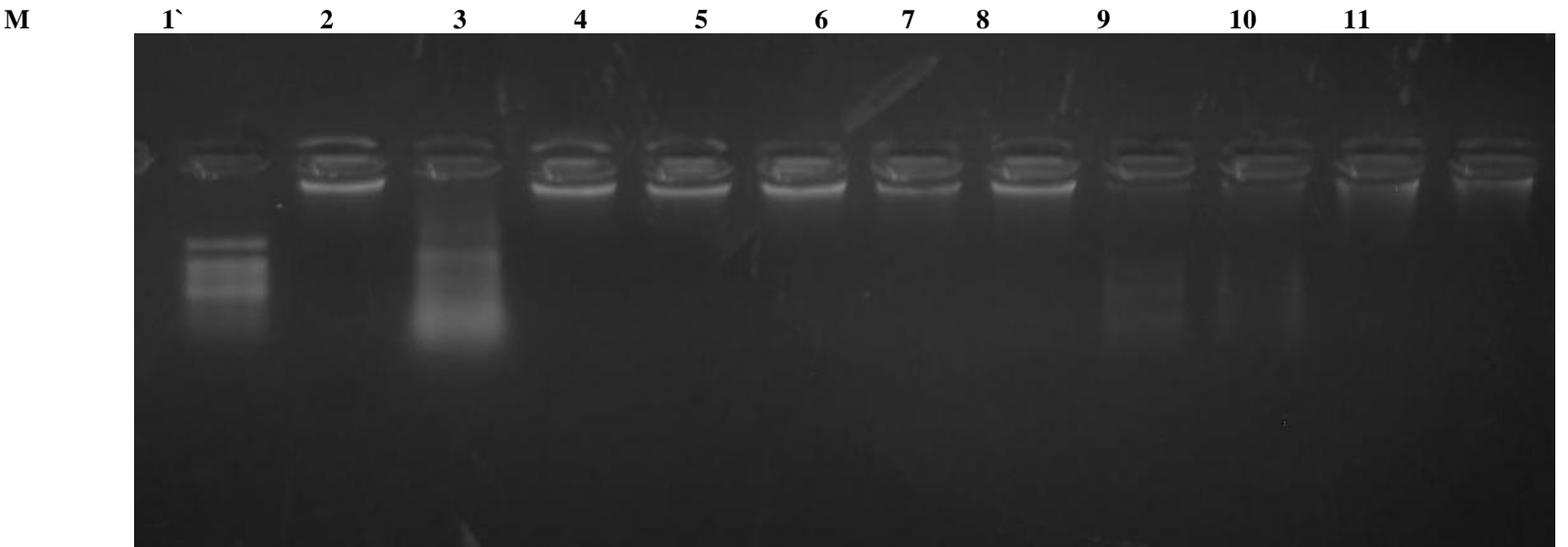

Fig. 4: Effects of inulin nanoparticles and/or SIL on DNA fragmentation of renal tissue in CPZ treated rats. Agarose gel electrophoretic pattern of DNA isolated from kidney tissue of different groups. Lane M: phi x marker, Lane 1: Control, Lane 2: low dose of INPs, Lane 3: high dose of INPs, Lane 4: CPZ, Lane 5: SIL . Lane 6: INPs (LD)+ SIL , Lane 7 : SIL + INPs(HD) , Lane 8: CPZ+ INPs(LD), Lane 9: CPZ + INPs (HD), Lane 10: CPZ+ SIL+ INPs(LD) and Lane 11: CPZ+ SIL +INPs(HD).

Lane M: DNA marker with 100bp

Lane1, 3, 4, 5, 6, 7, 10 \& 11: DNA without streaks or laddering

Lane 2: DNA with marked streaks and laddering (fragmented)

Lane 8 \& 9: DNA with little streaks and laddering. 


\section{Histological examination}

The microscopic examination of hepatic sections of the control rats showed the normal structure of the cords of the hepatocytes, the central vein and the blood sinusoids (Fig. 5A). The liver section of CPZ-treated animals showed congestion and fibrous thickening of the portal tract with elongated bile cannaliculi and the hepatocytes showed fatty droplets, necrotic cytoplasm and pyknotic or apoptic nuclei (Fig. 5B). The liver section of animals received INPs (LD) showed few inflammatory cells around the portal tract, fatty changes and apoptotic cells around the central vein (Fig. 5C).
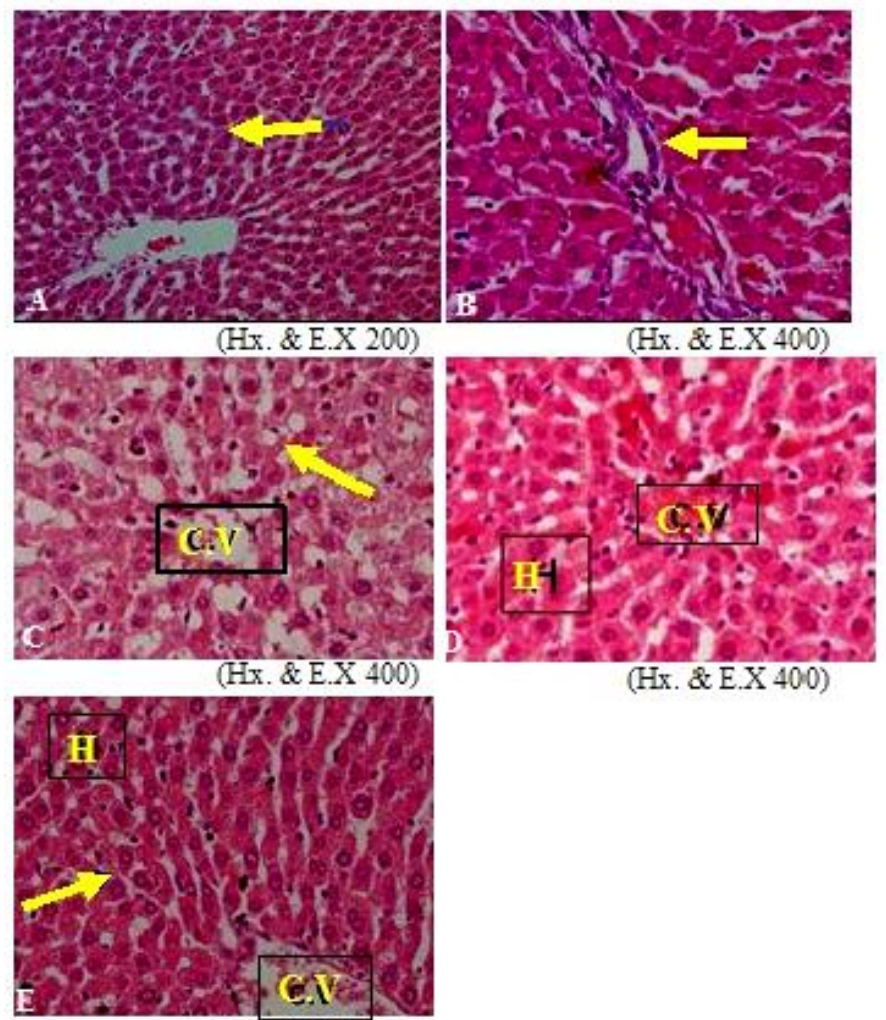

(Hx. \& E.X 400)

(Hx. \&EX 400)

Fig. 5: A photomicrograph of a liver section of (A) control rat showing cords of hepatocytes radiating from the central vein with blood sinusoids in between, (B) CPZ-treated rat showing congestion and fibrous thickening of the portal tract with elongated bile cannaliculi, the hepatocytes showing fatty droplets necrotic cytoplasm and pyknotic or apoptic nuclei, (C) rat treated with INPs (LD) showing few inflammatory cells around the portal tract (blue arrow), fatty changes and apoptotic cells around the central vein, (D) rats treated with INPs (HD) showing no significant changes in liver cells around the central vein, few inflammation, necrosis and bile ducts proliferation around the portal tract with normal hepatocellular morphology and (E) rats treated with SIL showing the central vein and normal hepatocellular architecture.

However, the animals treated with INPs (HD) showed insignificant changes in liver cells around the central vein, few inflammation, necrosis and bile ducts proliferation around the portal tract with normal hepatocellular morphology (Fig. 5D). Animals treated with SIL alone showed normal central vein and normal hepatocellular architecture (Fig. 5E). The microscopic examination of the liver sections of animals treated with SIL plus
INPs (LD) showed few inflammatory cells around blood vessels and nearly normal hepatic cells (Fig. 6A).
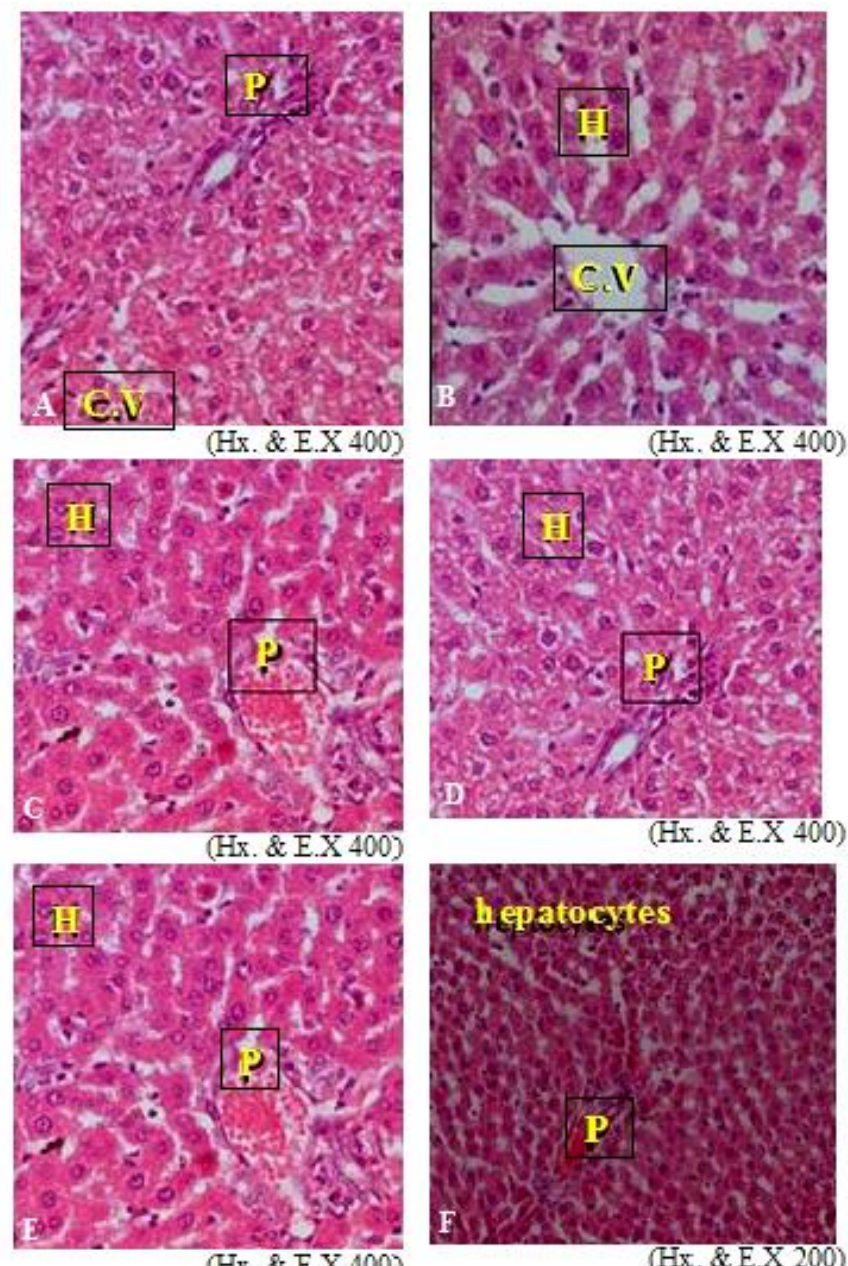

(Hx. \& E.X 400)

Fig. 6: A photomicrograph of a liver section of (A) rats treated with INPs (LD) and SIL showing few inflammatory cells around blood vessels and nearly normal hepatic cells, (B) rats treated with INPs (HD) and SIL showing nearly normal hepatocytes around the central vein, hepatocytes necrosis (black arrow), fatty droplets ground glass appearance and loss of nuclei or pyknotic nuclei with eosinophilic cytoplasm, (C) treated with CPZ plus INPs (LD) showing few inflammatory cells around blood vessels, nearly normal hepatocytes and focal apoptosis of some hepatocytes, (D) rats treated with CPZ plus INPs (HD) showing few inflammatory cells around portal tracts and the tissue architecture are distorted, (E) rats treated with CPZ plus SIL and INPs (LD) showing few inflammatory cells around blood vessels and nearly normal hepatocytes, some apoptotic cells are still present and (F) rats treated with CPZ plus SIL and INPs (HD) showing inflammatory cells around the elongated portal tract and relatively normal appearance of the majority of hepatocytes. Few Fatty droplets were still noticed.

The liver sections of the animals treated with SIL plus INPs (HD) showed nearly normal hepatocytes around the central vein, few hepatocytes necrosis, fatty droplets ground glass appearance and loss of nuclei or pyknotic nuclei with eosinophilic cytoplasm (Fig. 6B). The histological examination of the liver sections of the rats treated with CPZ plus INPs (LD) showed few inflammatory cells around the blood vessels and nearly normal hepatocytes with focal apoptosis of some hepatocytes (Fig. 6C). The liver sections of the animals treated with CPZ plus INPs (HD) 
showed few inflammatory cells around portal tracts and the tissue architecture are distorted (Fig. 6D). The microscopic examination of liver sections of the animals treated with CPZ plus SIL and INPs (LD) showed few inflammatory cells around blood vessels, nearly normal hepatocytes but some apoptotic cells are still present (Fig. 6E). However, the liver sections of the rats treated with $\mathrm{CPZ}$ plus SIL and INPs (HD) showed inflammatory cells around the elongated portal tract and relatively normal appearance of the majority of hepatocytes but few fatty droplets were still noticed (Fig. 6F). The examination of renal sections of the control rats revealed the normal proximal, distal, convoluted tubules and glomeruli with preserved renal space (Fig. 7A).
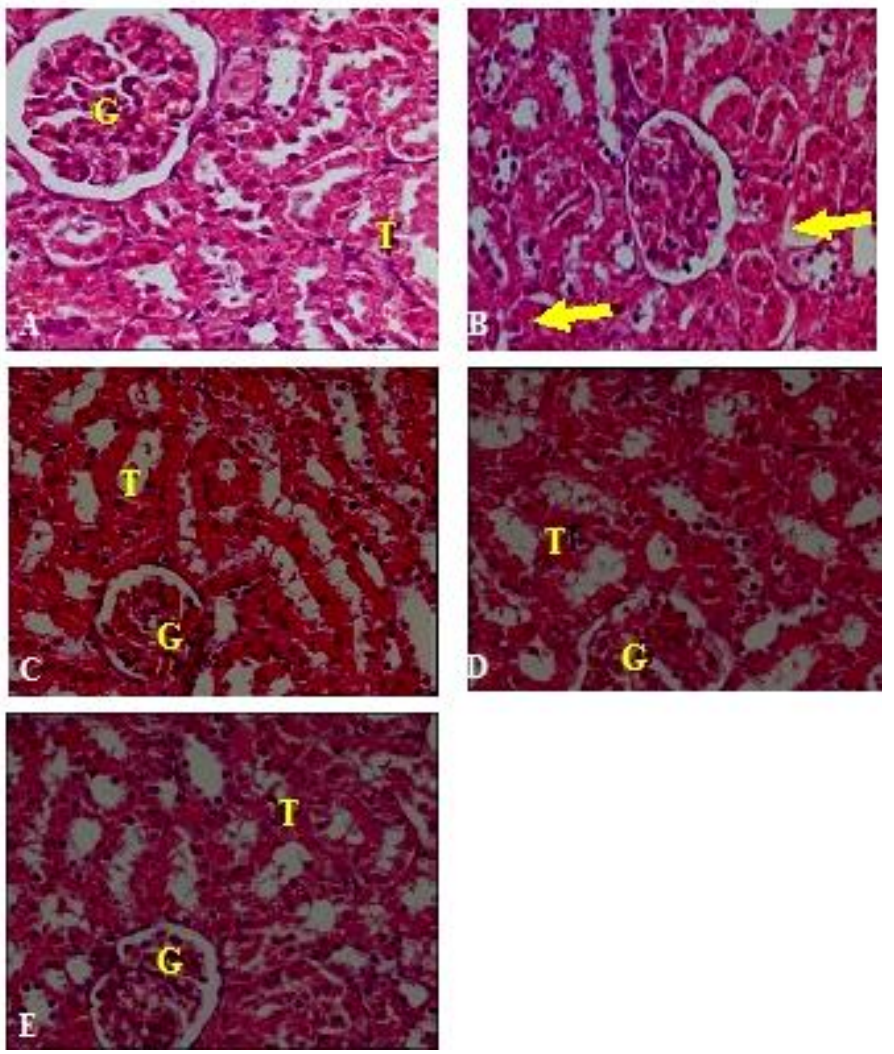

Fig. 7: A photomicrograph of a kidney cortex of (A) control rat showing normal proximal and distal and convoluted tubules (T) and a glomerule (G) with preserved renal space, (B) rat treated with $\mathrm{CPZ}$ showing interstitial hemorrhage and inflammation (blue arrow), some glomeruli are destroyed and tubular epithelial cells are swelling with pyknotic nuclei (red arrow) and detached the basement membrane, (C) rats treated with INPs (LD) showing nearly normal renal tubules $(\mathrm{T})$ and a glomerule $(\mathrm{G})$ with preserved renal space, (D) rat treated with INPs (HD) showing most of tubules is dilated having cellular debris in their lumen. Few changes in renal corpuscles with enlarged glomerule $(G)$ and obliterated urinary space and (E) rat treated with SIL showing most of renal tubules and corpuscles are nearly normal.

(Hx. \&E.X400)

The renal cortex of CPZ-treated animals showed interstitial hemorrhage and inflammation. Some glomeruli are destroyed; the tubular epithelial cells are swelling with pyknotic nuclei and detached the basement membrane (Fig. 7B). The kidney cortex of animals treated with INPs (LD) showed the nearly normal renal tubules and glomeruli with preserved renal space (Fig. 7C). However, the renal cortex of rats treated with INPs (HD) showed that most of tubules are dilated having cellular debris in their lumen. Few changes in renal corpuscles with enlarged glomeruli and obliterated urinary space (Fig. 7D). The kidney cortex of animals treated with SIL showed the nearly normal structure of most of renal tubules and corpuscles (Fig. 7E). The cortex of animals treated with SIL plus INPs (LD) showed shrunken glomerular capillaries, interstitial tubular hemorrhage and most of renal tubules are nearly normal (Fig. 8A).
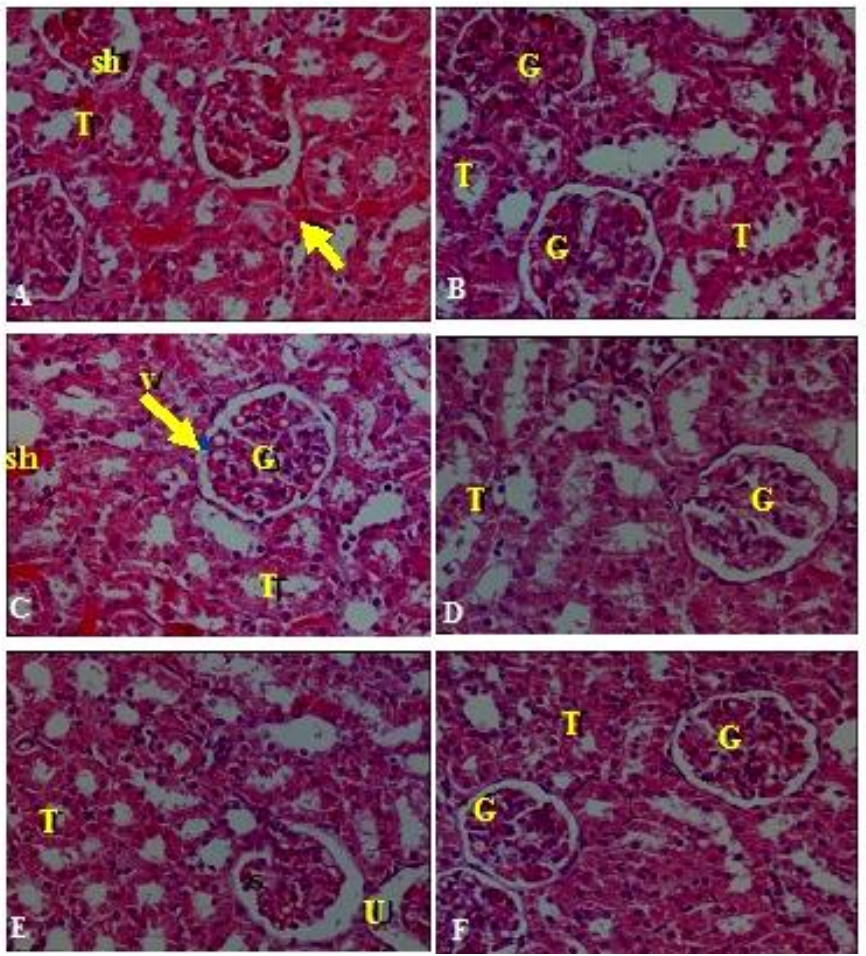

Fig. 8: A photomicrograph of a kidney cortex of (A) rat treated with SIL plus INPs (LD) showing shrunken glomerular (sh) capillaries. Interstitial tubular hemorrhage and most of renal tubules are nearly normal, (B) rat treated with SIL plus INPs (HD) showing a normal renal corpuscle (G), some of renal tubules have wide lumen with loss of their apical brush border (T) and few exfoliated cells in their lumen, (C) rat treated with CPZ plus INPs (LD) showing vacuolated capillaries of renal corpuscle $(\mathrm{G})$, interstitial necrosis. Most of renal tubules are nearly normal, (D) rat treated with CPZ plus INPs (HD) showing most of renal tubules and corpuscle are nearly normal few focal of necrosis can be seen, (E) rat treated with CPZ plus SIL and INPs (LD) showing most of renal tubules are nearly normal $(\mathrm{T})$ and shrunken in corpuscle capillaries with wide urinary space $(\mathrm{U})$ and $(\mathbf{F})$ rat treated with CPZ plus SIL and INPs (HD) showing focal necrosis in tubules and capillaries tufts but most of renal tubules and renal corpuscles are nearly normal ( $\mathrm{T} \& \mathrm{G})$.

(Hx. \& E.X400)

However, the kidney cortex of rats treated with SIL plus INPs (HD) showed the normal renal corpuscle, some of the renal tubules have wide lumen with the loss of their apical brush border and few exfoliated cells in their lumen (Fig. 8B). The renal cortex of rats treated with CPZ plus INPs (LD) showed vacuolated capillaries of the renal corpuscle, interstitial necrosis and most of the renal tubules are nearly normal (Fig. 8C). Moreover, the renal cortex of the animals treated with CPZ plus INPs (HD) showed the 
nearly normal of most renal tubules and corpuscle and few focal of necrosis can be seen (Fig. 8D). The renal cortex of the animals treated with CPZ plus SIL and INPs (LD) showed the nearly normal renal tubules but shrunken in corpuscle capillaries with wide urinary space were also seen (Fig. 8E). The renal cortex of the rats treated with CPZ plus SIL and INPs (HD) showed focal necrosis in tubules and capillary tufts but most of renal tubules and renal corpuscles are nearly normal (Fig. 8F).

\section{DISCUSSION}

Several mechanisms were suggested for the hepatotoxicity of $\mathrm{CPZ}$ however; lipid peroxidation, oxidative stress and the disturbances in the antioxidant defense system are the main factors responsible the intoxication of CPZ. In the current study, we evaluated the effect of CPZ administration on liver and kidney and the possible protective role of SIL plus INPs in rats. The selective doses of CPZ, SIL and INPs were literature based (Bratislav et al., 2017; Reshi et al., 2017; Rault-Nania et al., 2007; respectively). The results reported herein revealed that the animals treated with CPZ showed a significant elevation in serum ALT, AST, ALP, TB, creatinine, urea, uric acid, LDH, cholesterol, triglycerides and LDL as well as MDA and NO in the liver and kidney tissues and serum cytokines TNF- $\alpha$. These changes were accompanied with a significant decrease in serum ATP and the antioxidant enzymes activity GPx, SOD and CAT in liver and kidney. Moreover, CPZ-treated animals also showed a significant increase in the percentage of DNA fragmentation in hepatic and renal tissues. These results indicated that $\mathrm{CPZ}$ induced liver and kidney injury and suggested that CPZ has cytotoxic effects. Similar results were reported by Yang et al. (2015) who indicated that $\mathrm{CPZ}$ disturbs the biochemical indices and lipid profile and suggested the cholestasis liver injury in rats. Moreover, the decrease in ATP level reported in the current study in rats treated with CPZ alone may be explained by the decrease of $\mathrm{Na}+\mathrm{K}+-$ ATPase activity as suggested previously (Ayala et al., 2014; Foiatto et al., 2016; Xu et al., 2010).

CPZ was reported to undergo several metabolic processes by the cytochrome $\mathrm{P} 450$ to produce the aromatic hydroxylation at the 7-position (Hartmann et al., 1983). These products include $N$-dealkylation and oxidation, aromatic hydroxylation, $S$-oxidation and conjugation with sulfonation, methylation and glucuronidation (Odontiadis and Rauw 2007). This metabolic process leads to the formation of reactive metabolites which bind to proteins and alter their function, leading to the loss of the catalytic activity of enzymes (Schiff et al. 2007). Previous reports also suggested that CPZ increased free radicals generation and disturbed the hepatic and renal antioxidant enzymes activities (Dejanovic et al., 2014; Xu et al., 2010). It is well documented that oxidative stress in an organ is resulted from the increase production of reactive oxygen species (ROS) and the decline of the defense system due to the reduction of antioxidant enzymes activity (Abdel-Wahhab et al., 2016; Ostojić et al., 2012). In the same concern, Jorgačević et al. (2014) reported that neutrophils and Kupffer cells represent important sources of ROS however; the principal sources of ROS inside the hepatocytes are cytochrome P450 2E1, mitochondria, cyclooxygenase, lipoxygenase and nicotinamide adenine dinucleotide phosphate oxidase as well as iron overload. Consequently, the decrease of hepatocytes antioxidant capacity contributes to the liver injury by ROS. In the current study, the decrease in GPx, SOD and CAT accompanied with the increase in MDA and NO in hepatic and renal tissue indicated the stressful and the oxidative stress in these organs. Furthermore, these disturbances in antioxidant/oxidant were correlated positively with the impairment of liver or kidney injury as suggested earlier (Hassan and Yousef, 2010). On the other hand, the generation of ROS induces lipid peroxidation (MDA) then the modification of DNA and protein in the cells. The production of MDA was reported to induce the damage of mitochondria, suppress the mitochondrial electron transport chain and promote the production of further ROS (Abdel-Wahhab et al., 2017). Moreover, the generation of ROS activates the stellate cells in the liver resulting in the deposition of extracellular matrix which contribute to the development of fibrosis or cirrhosis in the liver tissue. The current results also showed that NO was increased in the liver and kidney tissues which may be suggested by the role of ROS in the increase of the synthesis of inducible iNOS (isoform nitric oxide synthase) leading to the increase of the level of NO (Jorgačević et al., 2014).

In a previous study, Shuhendler et al. (2014) reported that the liver is the principal organ subjected to severe alterations resulting from the increase in the constant concentration of ROS including the reactive nitrogen species. Actually, ROS affect the side chains of fatty acids in the lipid molecules present in the cells membrane specially the mitochondrial membranes, which exposed directly and continuously to the superoxide anion $\left(\mathrm{O}^{2 \bullet-}\right)$ produced during the respiration of cells. These events as well as the machinery of protein synthesis, lead to the damage of macromolecules inside the mitochondria, especially protein, mtDNA and lipids consequently the mitochondrial dysfunction, energy depletion and the death of cells (Casini et al., 1997). These molecular processes trigger a further increase in the steady concentration of ROS, resulting in energy depletion leading to cell death, which eventually damages the organ and its function (Sundaram et al., 2014).

The results of histological examination of the liver sections showed congestion and fibrous thickening of the portal tract with elongated bile cannaliculi and the hepatocytes showed fatty droplets necrotic cytoplasm and pyknotic or apoptotic nuclei. Moreover, the kidney sections showed interstitial hemorrhage and inflammation with destroyed glomeruli, tubular epithelial cells swelling with pyknotic nuclei and detached the basement membrane. These findings were similar to those reported by Yang et al. (2015) in the liver and Foiatto et al. (2016) in the kidney. In the current study, treatment with SIL alone did not show any significant changes in most of the tested parameters. On the contrary, it improved the antioxidant capacity and decreased the oxidative stress markers. These results are in accordance with the 
previous reports suggested that SIL possess antioxidant, antiapoptotic, anti-inflammatory and immunomodulatory properties (Al-Rasheed et al., 2015, 2016; Fraschini et al., 2002; Karimi et al., 2011; Pradeep et al., 2007). The hepatoprotective role of SIL was suggested to be due to its enhancement of CYP2E1 activity which has a major role in drug metabolism (Dejanovic et al., 2014; Jorgačević et al., 2014; Mahli et al., 2015; Wong et al., 1998).

In this study, animals treated with INPs (LD0 or INPs (HD) were comparable to the control group in most of the tested parameters. However; some parameters were significantly different than the control, but generally these changes were not in the critical level. Moreover, both groups treated with of INPs (LD) and INPs (HD) plus SIL were comparable to the control and these treatments improved the lipid profile levels and the antioxidant enzymes activity. In this concern, Kaur and Gupta, (2002) reported that inulin contains oligofructose which inhibits fatty acid synthesis and has a prebiotic effect and decrease total lipids, triglyceride, LDL and cholesterol through the inhibition of hydroxyl methyl glutaryl-CoA reductase (Brosnahan and Fraer, 2009), but it increased HDL, total protein and albumin. Moreover, it was reported that inulin showed antioxidant properties, increased the activity of antioxidant enzymes (Atta et al., 2010) and has a free radical scavenging activity (Hassan and Yousef, 2010). Additionally, inulin also has prebiotic effects and supports beneficial bacteria in the gut (Hartzell et al., 2013), stimulate the production of microbial short chain fatty acid, mainly the production of butyrate (Welters et al., 2002) which is a suitable source of energy for colonocytes (Hartzell et al., 2013) and has anti-inflammatory properties (Inan et al., 2000).

The results of the current study revealed that coadministration of INPs at the low or the high dose plus SIL succeeded to counteract the hazardous effects of CPZ on liver and kidney and improved the histological pictures of these organs. The resulted improvement was more pronounced in the group received the high dose of INPs.

These results suggested that besides the hepatoprotective effects of INPs, it enhanced the hepatoprotective effects of SIL, since INPs acted as a delivery for SIL and improved its solubility thus it improves the effectiveness of SIL. It was reported that in oral administration, drugs should be dissolved before the absorption in the intestine membrane and the bioavailability of drugs with low aqueous solubility (SIL) is poor due its slowly dissolving in the intestines (Mensink et al., 2015).

Consequently, the promise strategy to be applied is to increase the rate of dissolution through the composition with a hydrophilic carrier to enhance the dispersion of the drug. If the soluble carrier dissolves rapidly, the poorly soluble drug is hydrated faster, thus; it dissolution faster. In the current study, INPs may be considered a solid dispersion (Srinarong et al., 2009; Visser et al., 2010) for SIL and may improve the rate of SIL release from the hydrophilic multiblock copolymer since INPs acted as a pore-former (Stanković et al., 2013).

\section{CONCLUSION}

The results of the present study indicated that CPZ induced a severe hepatonephrotoxicity in animal model as manifested by the significant disturbances in serum biochemical parameters, inflammatory cytokines, lipid profile, antioxidant enzymes activity, oxidative stress markers and the histological changes in liver and kidney. INPs alone or plus SIL showed a protective effects against CPZ-induced oxidative stress, cytotoxicity and the histological changes in both organs. INPs at the low or high dose alone or plus SIL succeeded to induce a significant protection against CPZ toxicity. This protection was more pronounced when animals treated with the high dose of INPs and may be due to the hepatoprotective effects of SIL and antioxidant properties of INPs. Moreover, INPs may enhance the solubility of SIL, prolonged its release and acted as pore-former. Consequently, INPs produced by the emulsion method may be promising hepatonephroprotective agent as well as a promising drug delivery of the poor water soluble drugs. Additional studies for the extrapolation of animal study to human should be done.

\section{ACKNOWLEDGMENTS}

This work was supported by National Research Center, Dokki, Cairo, Egypt, Project No. 11090341, Faculty of Pharmacy, Misr University for Science and Technology, Cairo, Egypt and Faculty of Pharmacy, Cairo University, Cairo, Egypt

Conflict of Interest: The authors declare that there are no conflicts of interest.

\section{REFERENCES}

Abdel-Wahhab MA, Aljawish A, El-Nekeety AA, Abdel-Aiezm $\mathrm{SH}$, Hassan NS. Chitosan nanoparticles plus quercetin suppress the oxidative stress, modulate DNA fragmentation and gene expression in the kidney of rats fed ochratoxin A-contaminated diet. Food Chem Toxicol, 2017; 99: 209-221.

Abdel-Wahhab MA, Salman AS, Ibrahim MIM, El-Kady AA, Abdel-Aziem SH, Hassan NS, Waly AI. Curcumin nanoparticles loaded hydrogels protects against aflatoxin $\mathrm{B}_{1}$-induced genotoxicity in rat liver. Food Chem Toxicol, 2016; 94:159-71.

Akerboom T, Schneider I, vom Dahl S, Sies H. Cholestasis and changes of portal pressure caused by chlorpromazine in the perfused rat liver. Hepatol, 1991; 13:216-221.

Al-Rasheed N, Faddah L, Al-Rasheed N, Bassiouni YA, Hasan IH, Mahmoud AM, Mohamad RA, Yacoub HI. Protective effects of silymarin, alone or in combination with chlorogenic acid and/or melatonin, against carbon tetrachloride-induced hepatotoxicity. Pharmacogn Mag, 2016; 12(3):S337-345.

Al-Rasheed N, Faddah L, Sharaf IA, Mohamed AM, AlRasheed N, Abdelbaky N. Assessment of the potential role of silymarin alone or in combination with Vitamin $\mathrm{E}$ and/or curcumin on the carbon tetrachloride induced liver injury in rat. Braz Arch Biol Technol, 2015; 58:833-842.

Antherieu S, Bachour-El Azzi P, Dumont J, Abdel-Razzak Z, Guguen-Guillouzo C, Formenty B, Robin MA, Guillouzo A. Oxidative stress plays a major role in chlorpromaz-ineinduced cholestasis in human HepaRG cells. Hepatol, 2013; 57:1518-1529. 
Atta AH, Elkoly, TA, Mouneir SM, Kamel G, Alwabel NA, Zaher S. Hepatoprotective effect of methanol extracts of Zingiber officinale and Cichorium intybus. Indian J Pharm Sci, 2010; 72(5): 564570.

Ayala A, Muñoz MF, Arguelles S. Lipid peroxidation: production, metabolism, and signaling mechanisms of malondialdehyde and 4-hydroxy-2-nonenal. Oxid Med Cell Longev, 2014; 2014:1-31.

Barclay T, Ginic-Markovic M, Cooper PD, Petrovsky N. Inulina versatile polysaccharide with multiple pharmaceutical and food chemical uses. J Excipients Food Chem, 2010; 1(3): 27-50.

Bissell DM, Gores GJ, Laskin DL and Hoofnagle JH. Druginduced liver injury: mechanisms and test systems. Hepatol, 2001; 33:1009-1013.

Brosnahan G, Fraer M. Chronic kidney disease: Whom to screen and how to treat, part 1: Definition, epidemiology, and laboratory testing. South J Med, 2009; 103(2): 104-106.

Bratislav D, Irena L, Milica N, Ivana S, Ana D, Sanda D, Ivana S. Effects of agmatine on chlorpromazine toxicity in the liver of Wistar rats: the possible role of oxidant/antioxidant imbalance. Exp Anim, 2017; 66(1):17-27.

Casini A, Ceni E, Salzano R, Biondi P, Parola M, Galli A, Foschi M, Caligiuri A, Pinzani M, Surrenti C. Neutrophilderived superoxid anion induces lipid peroxidation and stimulates collagen synthesis in human hepatic stellate cells:role of nitric oxide. Hepatol, 1997; 25:361-367.

Comelli MC, Mengs U, Schneider C, Prosdocimi M. Toward the definition of the mechanism of action of silymarin: Activities related to cellular protection from toxic damage induced by chemotherapy. Integr Cancer Ther, 2007, 6:20-29.

Davies C, Tournier C. Exploring the function of the JNK (c-Jun $\mathrm{N}$-terminal kinase) signalling pathway in physiological and pathological processes to design novel therapeutic strategies. Biochem Soc Trans, 2012; 40(1):85-89.

De Haan S, Liu X. Chlorpromazine dose for people with schizophrenia. Schizophr Bull, 2009; 35:491-492.

Dejanovic B, Stevanovic I, Ninkovic M, Stojanovic I, VukovicDejanovic V. Protective effect of agmatine in acute chlorpromazine hepatotoxicity in rats. Acta Vet Brno, 2014; 83: 305-312.

Derby LE, Gutthann SP, Jick H, Dean AD. Liver disorders in patients receiving chlorpromazine or isoniazid. Pharmacother, 1993; 13:353-835.

Drury RAV, Wallington EA. Carltons Histological techniques, $5^{\text {th }}$ ed. 1980; Oxford University Press, New York, Pronto. 206SY.

Foiatto J, Nicolau Czeczko NG, Gabrie E, Wietzikoski G, Malafaia O, Filho TB, Oliveira AM, Gomes RPX. Influence of chlorpromazine on renal histology of rats submitted to ischemia and reperfusion injury. Acta Cirúrgica Brasileira, 2016; 31 (11): 759-764.

Fraschini F, Demartini G, Esposti D. Pharmacology of silymarin. Clin Drug Investig, 2002; 22:51-65.

Gandhi A, Guo T, Ghose R. Role of c-Jun N-terminal kinase (JNK) in regulating tumor necrosis factor-alpha (TNF-alpha) mediated increase of acetaminophen (APAP) and chlorpromazine (CPZ) toxicity in murine hepatocytes. J Toxicol Sci, 2010; 35:163-173.

Gandhi A, Guo T, Shah P, Moorthy B, Ghose R. Chlorpromazine-induced hepatotoxicity during inflammation is mediated by TIRAP-dependent signaling pathway in mice. Toxicol Appl Pharmacol, 2013; 266:430-438.

Hartmann F, Gruenke LD, Craig JC. Chlorpromazine metabolism in extracts of liver and small intestine from guinea pig and from man. Drug Metab Dispos, 1983; 11: 244-248.

Hartzell LA, Maldonado-Gómez XM, Yang J, Hutkins WR, Rose JD. In vitro digestion and fermentation of 5- formyl-aminosailcylateinulin : A potential prodrug of 5- aminosalicylic acid. Bioact Carbohydr Dietary Fibre, 2013; 2: 8-14.

Hassan HA, Yousef MI. Ameliorating effect of chicory (Cichorium intybus L.) supplemented diet against nitrosamine precursorsinduced liver injury and oxidative stress in male rats. Food Chem Toxicol, 2010; 48: 2163-2169.
Inan MS, Rasoulpour RJ, Yin L, Hubbard AK, Rosenberg DW, Giardina C. The luminal short-chain fatty acid butyrate modulates NFkappa B activity in a human colonic epithelial cell line. Gastroenterol J, 2000; 118: 724-734.

Jorgačević B, Mladenović D, Ninković M, Prokić V, Stanković MN, Aleksić V, Cerović I, Vukićević RJ, Vučević D, Stanković M, Radosavljević T. Dynamics of oxidative/nitrosative stress in mice with methionine-choline-deficient diet-induced nonalcoholic fatty liver disease. Hum Exp Toxicol, 2014; 33: 701-709.

Karimi G, Vahabzadeh M, Lari P, Rashedinia M, Moshiri M. "Silymarin", a promising pharmacological agent for treatment of diseases. Iran J Basic Med Sci, 2011; 14:308-317.

Kaur N, Gupta AK. Applications of inulin and oligofructosein health and nutrition. Biosci J, 2002; 27(7): 703-714.

Korbelik M, Cooper PD. Potentiation of photodynamic therapy of cancer by complement: the effect of gamma-inulin. Brit J Cancer, 2007; 96: 67-72.

Letexier D, Diraison F, Beylot M. Addition of inulin to a moderately highcarbohydrate diet reduces hepatic lipogenesis and plasma triacylglycerol concentrations in humans. Am J Clin Nutr, 2003; 77:559564.

Liber A, Szajewska H. Effects of inulin-type fructans on appetite, energy intake, and body weight in children and adults: systematic review of randomized controlled trials. Ann Nutr Metab, 2013; 63:42-54.

Lin CC, Hsu YF, Lin TC, Hsu FL, Hsu HY. Antioxidant and hepatoprotective activity of punicalagin and punicalin on carbon tetrachloride-induced liver damage in rats. J Pharm Pharmacol, 1998; 50: 789-794.

Mahli A, Koch A, Czech B, Peterburs P, Lechner A, Haunschild J, Müller M, Hellerbrand C. Hepatoprotective effect of oral application of a silymarin extract in carbon tetrachloride-induced hepatotoxicity in rats. Clin Phytosci, 2015; 1:5.

Mazloom A, Hashemiravan M, Farhadyar N, Farhadyar F. Influence of inulin and $\beta$-cyclodextrin on the properties of blueberry nanoemulsion and its microcapsules. Int J Bio-Inorg Hybd Nanomat, 2012; 1(2): 93-96.

McRorie JW, Gibb RD, McKeown NM. Inulin-type fructans have no significant beneficial effects on lipid or glucose metabolism. Eur J Clin Nutr, 2017 doi: 10.1038/ejcn.2017.15. [Epub ahead of print]

Mensink MA, Frijlink HW, van der Voort Maarschalk K, Hinrichs WL. Inulin, a flexible oligosaccharide. II: Review of its pharmaceutical applications. Carbohydr Polym, 2015; 134:418-28.

Morachis JM, Mahmoud EA, Almutairi A. Physical and chemical strategies for therapeutic delivery by using polymeric nanoparticles. Pharmacol Rev, 2012; 64(3):505-519.

Odontiadis J, Rauw G. High performance liquid chromatographic analysis of psychotropic and endogenous compounds. In: Handbook of neurochemistry and molecular neurobiology. $3^{\text {rd }}$ ed. Edited by Baker G, Dunn S, Holt A, Springer Science Business Media, 2007; New York, pp.34

Ostojić JN, Mladenović D, Ninković M, Vučević D, Bondžić K, Ješić-Vukićević R, Radosavljević T. The effects of cold-induced stress on liver oxidative injury during binge drinking. Hum Exp Toxicol, 2012; 31: 387-396.

Pang L, Zhang C, Qin J, Han L, Li R, Hong C, He H, Wang J. A novel strategy to achieve effective drug delivery: exploit cells as carrier combined with nanoparticles. Drug Deliv, 2017; 24(1):83-91.

Perandones CE, lllera AV, Peckham D, Stunzl LL, Ashman RF. Regulation of apoptosis in vitro in mature murine spleen T-cell. J Immunol, 1993; 151: 3521-3529.

Pourghassem Gargari B, Dehghan P, Aliasgharzadeh A, Asghari Jafar-Abadi M. Effects of high performance inulin supplementation on glycemic control and antioxidant status in women with type 2 diabetes. Diabetes Metab J, 2013; 37: 140-148.

Pradeep K, Mohan CV, Gobianand K, Karthikeyan S. Silymarin modulates the oxidant-antioxidant imbalance during diethylnitrosamine induced oxidative stress in rats. Eur J Pharmacol, 2007; 560:110-116.

Rault-Nania M, Demougeot C, Gueux E, Berthelot A, Dzimira S, Rayssiguier Y, Rock E, Mazur A. Inulin supplementation prevents high 
fructose diet-induced hypertension in rats. Clin Nutr, 2008; 27(2): 276282 .

Reshi MS, Shrivastava S, Jaswal A, Sinha N, Uthra C, Shukla S. Gold nanoparticles ameliorate acetaminophen induced hepato-renal injury in rats. Exp Toxicol Pathol, 2017; 69(4):231-240.

Reukov V, Maximov V, Vertegel A. Proteins conjugated to poly (butyl cyano- acrylate) nanoparticles as potential neuroprotective agents. Biotechnol Bioeng, 2011; 108(2):243-252.

Ruoslahti E. Peptides as targeting elements and tissue penetration devices for nanoparticles. Adv Mater, 2012; 24(28):37473756.

SAS Institute, Inc. SAS User's Guide: Statistics. SAS Institute. Cary, NC, 1982.

Schiff, E.R., Sorrell, M.F., Maddrey EC. Schiff's diseases of the liver. $10^{\text {th }}$ ed. Lippincott Williams and Silkins, 2007; Philadelphia, Penn. pp. 1010

Shuhendler AJ, Pu K, Cui L, Uetrecht JP, Rao J. Real-time imaging of oxidative and nitrosative stress in the liver of live animals for drug-toxicity testing. Nat Biotechnol, 2014; 32: 373-380.

Silva DG, Cooper PD, Petrovsky N. Inulin-derived adjuvants efficiently promote both Th1 and Th2 immune responses. Immunol Cell Biol, 2004; 82: 611-616.

Srinarong P, Faber JH, Visser MR, Hinrichs WLJ, Frijlink HW. Strongly enhanced dissolution rate of fenofibrate solid dispersion tablets byincorporation of super-disintegrants. Eur J Pharma Biopharm, 2009; 73(1): 154-161

Stanković M, de Waard H, Steendam R, Hiemstra C, Zuidema J, Frijlink HW, Hinrichs WL. Low temperature extruded implants based on novel hydrophilic multiblock copolymer for long-term protein delivery. Eur J Pharm Sci, 2013; 49(4):578-87.

Stanwick JC, Baumann MD, Shoichet MS. Enhanced neurotrophin-3 bioactivity and release from a nanoparticle-loaded composite hydrogel. J Control Release, 2012; 60(3):666-675.

Sulaiman AA, Al-Shawi NN, Jwaied AH, Mahmood DM, Hussain SA. Protective effect of melatonin against chlorpromazineinduced liver disease in rats. Saudi Med J, 2006; 27:1477-1482.

Sundaram MS, Hemshekhar M, Thushara RM, Santhosh MS, Kumar SK, Paul M, Devaraja S, Kemparaju K, Rangappa KS, Girish KS. Tamarind seed extract mitigates the liver oxidative stress in arthritic rats. Food Funct, 2014; 5: 587-597.

Uzbekova D, Makarova V, Khvoynitskaya L, Mirgorodskaya L. Protective effects of beehive products and lactulose on chlorpromazineinduced liver damage in rats. J Hepatol, 2002; 36:165.

van Loo J, Coussement P, de Leenheer L, Hoebregs H, Smits G. On the presence of inulin and oligofructose as natural ingredients in the Western diet. Crit Rev Food Sci Nutr, 1995; 35:525-552.
Vasquez KO, Peterson JD. Early detection of acute druginduced liver injury in mice by non-invasive NIR fluorescence imaging. $\mathrm{J}$ Pharmacol Exp Ther, 2017(1): 23. pii: jpet.116.238378. doi: 10.1124/jpet.116.238378. [Epub ahead of print]

Visser MR1, Baert L, Klooster Gv, Schueller L, Geldof M, Vanwelkenhuysen I, de Kock H, De Meyer S, Frijlink HW, Rosier J, Hinrichs WL. Inulin solid dispersion technology toimprove the absorption of the BCS Class IV drug TMC240. Eur J Pharma Biopharma, 2010; 74(2): 233-238.

Waller RA, Duncan DB. A Bayes rule for the symmetric multiple comparison problems. J Am Stat Assoc, 1969; 64: 1484-1503.

Welters CF, Heineman E, Thunnissen FB, Bogaard AE, Soeters PB, Baeten CG. Effectofdietary inulin supplementation on inflammation of pouchmucosain patients with anilealpouch-analanastomosis. Di Colon Rectum, 2002; 45: 621-627.

Wichienchot S, Thammarutwasik P, Jongjareonrak A, Chansuwan W, Hmadhlu P, Hongpattarakere T, Itharat A, Ooraikul B. Extraction and analysis of prebiotics from selected plants from southern Thailand. Songklanakarin J Sci Technol, 2011; 33: 517-523.

Wong FW, Chan WY, Lee SS. Resistance to carbon tetrachloride-induced hepatotoxicity in mice which lack CYP2E1 expression. Toxicol Appl Pharmacol, 1998; 153:109-118.

$\mathrm{Xu}$ B, Xu ZF, Deng Y, Yang JH. Protective effects of chlorpromazine and verapamil against cadmium-induced kidney damage in vivo. Exp Toxicol Pathol, 2010; 62(1):27-34

Yang Q, Yang F, Tang X, Ding L, Xu Y, Xiong Y, Wang Z, Yang L. Chlorpromazine-induced perturbations of bile acids and free fatty acids in cholestatic liver injury prevented by the Chinese herbal compound Yin-Chen-Hao-Tang. BMC Complement Altern Med, 2015; 15:122. doi:10.1186/s12906-015-0627-2.

Ziv-Polat O, Skaat H, Shahar A, Margel S. Novel magnetic fibrin hydrogel scaffolds containing thrombin and growth factors conjugated iron oxide nanoparticles for tissue engineering. Int $\mathrm{J}$ Nanomedicine, 2012; 7:1259-1274.

\section{How to cite this article:}

Abdel-Wahhab MA, Eid NI, Ahmed LA, Ragab GM, El-Nekeety AA, El-Hakim MM, Hassan NS, Inulin nanoparticles and silymarin counteract chlorpromazine-induced injury in the liver and kidney of rats. J App Pharm Sci, 2017; 7 (08): 104-115. 